\title{
Hubungan antara Kepercayaan Diri dengan Prestasi Belajar dan Perencanaan Karir Siswa
}

\author{
Indra Bangkit Komara \\ Pondok Pesantren Modern Islam Assalam \\ Jl. Garuda Mas, Pabelan, Sukoharjo - Surakarta, Jawa Tengah, Indonesia \\ Email: indrabangkitkomara@gmail.com
}

\begin{abstract}
This research aimed to know the relationship between self confidence with students' achievement and career planning of grade VIII SMP Negeri 3 Bantul. The research used quantitative approach with correlation type. Research subjects were 93 students who were taken through random sampling technique from 186 populations of students. Data analysis technique which was used to know correlation between variables was double linear correlation. The analysis result showed determinate coefficient value $\left(\mathrm{R}^{2}\right)=0.528$, it means that the high expectation for career planning was caused by self confidence and students' achievement was $52.8 \%$ and the rest $47.2 \%$ was caused by other variables such as physics, psychology, and environment. It can be concluded that there re is a positive correlation between self confidence and students' achievement with students' career planning of grade VIII SMP Negeri 3 Bantul. The research results are beneficial for counselors as the description of self confidence, students' achievement, and career planning condition which can be considered in arranging guidance and counseling services program for students at school.
\end{abstract}

Keywords: self confidence, students' achievement, career planning

\begin{abstract}
Penelitian ini bertujuan untuk mengetahui hubungan antara kepercayaan diri dengan prestasi belajar dan perencanaan karir siswa kelas VIII SMP Negeri 3 Bantul. Pendekatan dalam penelitian ini kuantitatif dengan jenis penelitian korelasi. Subjek penelitian berjumlah 93 siswa yang diambil melalui teknik random sampling dari populasi sebanyak 186 siswa. Teknik analisis data untuk mengetahui korelasi antar variabel menggunakan korelasi linier berganda. Hasil analisis penelitian ini menunjukan nilai koefisien determinasi $\left(\mathrm{R}^{2}\right)=0,528$ yang mempunyai arti bahwa tingginya keinginan siswa untuk merencanakan karir disebabkan oleh kepercayaan diri dan prestasi belajar siswa sebesar 52,8\% dan sisanya sebesar 47,2\% disebabkan oleh variabel lain seperti jasmani, psikologis dan lingkungan. Hasil penelitian dapat disimpulkan ada hubungan positif antara kepercayaan diri dan prestasi belajar dengan perencanaan karir siswa kelas VIII SMP Negeri 3 Bantul. Hasil penelitian ini bermanfaat bagi konselor sebagai gambaran tentang kondisi kepercayaan diri, prestasi belajar, dan perencanaan karir siswa yang dapat dijadikan bahan pertimbangan dalam menyusun program layanan bimbingan dan konseling bagi siswa di sekolah.
\end{abstract}

Kata kunci: kepercayaan diri, prestasi belajar, perencanaan karir

\section{Pendahuluan}

Pendidikan merupakan bagian terpenting dalam aspek kehidupan sebagai bekal dalam rangka membentuk manusia yang cerdas dan berkualitas. Sesuai dengan Undang-undang Sistem Pendidikan Nasional Republik Indonesia No 20 Tahun 2003 Bab II Pasal 3 yaitu pendidikan nasional bertujuan untuk berkembangnya potensi peserta didik agar menjadi manusia yang beriman dan bertaqwa kepada Tuhan Yang Maha Esa, berakhlak mulia, sehat, berilmu, cakap, kreatif, mandiri dan menjadi warga negara yang demokratis serta bertanggung jawab. Tertulis dalam Undangundang Sistem Pendidikan Nasional Republik Indonesia No. 20 Tahun 2003 Pasal 1 Ayat 1 bahwa yang dimaksud dengan pendidikan adalah usaha sadar dan terencana untuk mewujudkan susana belajar dan proses pembelajaran agar peserta didik secara aktif mengembangkan potensi dirinya untuk memiliki kekuatan spiritual keagamaan, pengendalian diri, kepribadian, kecerdasan, akhlak mulia, serta keterampilan yang diperlukan dirinya, masyarakat, bangsa, dan negara.

Pemerataan pendidikan di daerah-daerah terpencil adalah sistem pendidikan yang menyediakan kesempatan seluas-luasnya kepada seluruh warga negara untuk memperoleh pendidikan secara merata, sehingga pendidikan menjadi salah satu tempat untuk membentuk generasi muda yang cerdas dan berakhlak mulia. Masalah dalam pemerataan pendidikan muncul karena kurangnya infrastruktur, sarana, dan prasarana sekolah serta tenaga pengajar yang 
masih kurang. Kekurangan fasilitas ini tentu akan menjadi penghambat majunya mutu pendidikan di Indonesia. Padahal mutu pendidikan hanya dapat dibangun oleh sistem pendidikan di sekolah yang baik sehingga melalui pendidikan mampu melahirkan generasi muda yang memiliki kepercayaan diri dan mempu bersaing serta memiliki prestasi.

Kepercayaan diri merupakan modal dasar yang paling utama dalam diri seseorang untuk bisa mengaktualisasikan diri. Percaya diri merupakan salah satu hasil karya dari aktualisasi diri yang positif, dengan memiliki kepercayaan diri siswa mampu mengembangkan bakat, minat dan potensi yang ada di dalam dirinya sehingga bisa berkembang menjadi sebuah kesuksesan atau yang di sebut dengan prestasi. Sikap percaya diri memiliki kontribusi yang besar terhadap motivasi siswa. Seperti dalam melaksanakan kewajiban siswa sebagai pelajar, melanjutkan pendidikan ke jenjang yang lebih tinggi dan dalam perencanakan karir, siswa perlu mengenali potensi diri, membuat target yang akan ditempuh dan mampu berkembang serta bersaing baik dalam dunia akademik maupun dunia karir siswa.

Prestasi belajar adalah salah satu tolak ukur kesuksesan bagi seorang siswa. Siswa yang berprestasi rata-rata memiliki kepercayaan diri yang tinggi. Hal tersebut dibuktikan dengan sikap, kesigapan, dan kesiapan siwa sebagai modeling atau siswa percontohan di kelasnya.

Penelitian yang di lakukan oleh Lilis Andriani dengan judul "Hubungan Rasa Percaya Diri Dengan Prestasi Belajar Siswa Pada Mata Pelajaran Geografi Kelas X Di SMA Negeri 4 Gorontalo", bertujuan untuk melihat seberapa besar hubungan rasa percaya diri dengan prestasi belajar siswa pada matapelajaran geografi kelas X di SMA Negeri 4 Gorontalo. Data hasil penelitian diperoleh persamaan regresi antara rasa percaya diri dengan prestasi belajar siswa, hubungan antara kedua variabel juga diperkuat dengan nilai koefisien korelasi antara kedua variabel rxy sebesar 0,6025. Hasil perhitungan koefisien korelasi sebesar 0,6025 ini mengindikasikan bahwa hubungan antara rasa percaya diri dengan prestasi belajar siswa adalah hubungan positif dan kuat. Kuatnya hubungan antara rasa percaya diri dengan prestasi belajar siswa adalah 36,3\%. Hal ini memberikan gambaran bahwa ada sebesar $36,3 \%$ variasi Prestasi Belajar Siswa yang dapat dijelaskan oleh rasa percaya diri siswa, sedangkan $63,7 \%$ ditentukan oleh faktor lain.

Kepercayaan diri sangat berpengaruh dan menentukan keberhasilan siswa dalam kehidupannya. Kepercayaan diri sangat mempengaruhi kesuksesan dalam belajar dan bekerja, dalam lingkungan keluarga, dan hubungan sosial dengan orang lain. Individu yang memiliki kepercayaan diri yang baik memiliki keyakinan dan selalu berusaha mengembangkan potensi diri secara maksimal serta menunjukan yang terbaik dari dirinya dibuktikan dengan sebuah prestasi. Sebaliknya siswa yang memiliki kepercayaan diri yang kurang baik, mereka tidak mampu mengambangkan bakat, minat, dan potensi yang ada di dalam dirinya dan tidak mampu mengaktualisasikan diri dengan maksimal serta bersifat pasif. Oleh karena itu, peranan guru bimbingan dan konseling sangat penting dalam upaya memberikan layanan pencegahan (preventif), informasi, motivasi, konseling individual, dan konseling kelompok bagi siswa.

Menurut Santrok (2007: 148) seiring dengan terbentangnya masa dewasa dan masa beranjak dewasa, prestasi berperan lebih penting dalam perkembangan, pekerjaan menjadi aspek utama dalam kehidupan, dan peranan karir juga menjadi semakin besar. Mengkaji dari pernyataan tersebut diketahui bahwa prestasi seseorang sangat berpengaruh pada sebuah pekerjaan yang menjadi aspek paling utama dalam meniti kehidupan baik dalam pendidikan maupun dalam perjalanan karir siswa. Perencanaan karir merupakan perkembangan sebuah perjalanan akademik siswa dalam meraih kesuksesan dalam belajar yang disebut dengan dengan prestasi.

Dalam rangka menghadapi Masyarakat Ekonomi Asean (MEA) sudah seharusnya siswa memiliki perencanaan karir yang matang sejak dini. Hal tersebut sesuai dengan salah satu tugas perkembangan yang harus di capai oleh siswa SMP yaitu memiliki wawasan persiapan karir. Pekerjaan merupakan salah satu proses perkembangan kehidupan manusia, berbicara mengenai pekerjaan ternyata tidak hanya sekedar bekerja saja melainkan banyak hal yang berada di dalamnya. Dengan bekerja, seseorang merasa lebih diakui, lebih percaya diri, merupakan bagian dari prestasi dan media bagi aktualisasi diri. Oleh sebab itu, mempersiapkan diri untuk menghadapi keputusan karir menjadi hal yang paling penting 
terutama bagi usia SMP dimana akan dihadapkan dua pilihan untuk sekolah lanjutan, yaitu SMA atau SMK. Mengkaji dari tugas perkembangan tersebut, seharusnya siswa memiliki wawasan persiapan karir, mampu memilih sekolah lanjutannya sebagai bentuk wujud dari perencanaan karir, mampu mempersiapkan diri dalam menghadapi persaingan perkembangan pasar global, serta mampu membuktikan bahwa Indonesia mampu dan layak bersaing dalam mempersiapkan pasar global yang di sebut dengan MEA.

Berdasarkan hasil wawancara peneliti dengan lima siswa kelas VIII di SMP Negeri 3 Bantul pada tanggal 29 Mei 2015, peneliti mengambil kesimpulan bahwa sebagian besar siswa kelas VIII belum mengetahui bakat dan minat dirinya, belum memiliki pandangan hidup untuk melanjutkan jenjang pendidikan ke sekolah lanjutan karena rata-rata memiliki alasan masih bingung menentukan sekolah dan sebagian besar pengambilan keputusan sekolah masih berdasarkan dorongan orang tua serta kurangnya informasi mengenai sekolah yang merupakan bagian dari sebuah perencanaan karir.

Hal ini dibenarkan oleh koordinator guru bimbingan dan konseling di SMP Negeri 3 Bantul pada tanggal 29 Mei 2015, bahwa siswa kelas VIII masih banyak yang memiliki permasalahan dalam belajarnya. Berdasarkan hasil analsis need asesment DCM diketahui bahwa 58\% siswa memiliki permasalahan belajar, dalam masalah pribadi siswa masih banyak yang belum mengetahui bakat dan minatnya sendiri, serta dalam hal karir belum memiliki perencanaan yang begitu matang melainkan mereka masih mencobacoba dan belum memantapkan pilihan melanjutkan ke SMA atau SMK serta tidak sedikit siswa yang menentukan pilihan sekolahnya dengan alasan keputusan berdasarkan dorongan dari orang tua.

Penelitian ini bertujuan untuk mengetahui hubungan antara kepercayaan diri dan prestasi belajar dengan perencanaan karir siswa kelas VIII SMP Negeri 3 Bantul. Perencanaan karir yang matang, merupakan salah satu faktor yang berpengaruh terhadap keberhasilan siswa di masa depan. Oleh karena itu, perlu untuk mengetahui faktor-faktor yang berhubungan dengan perencanaan karir. Dalam penelitian ini difokuskan pada hubungan kepercayaan diri dan prestasi belajar siswa. Hasil penelitian ini bermanfaat bagi konselor sebagai gambaran tentang kondisi kepercayaan diri, prestasi belajar, dan perencanaan karir siswa yang dapat dijadikan bahan pertimbangan dalam menyusun program layanan bimbingan dan konseling bagi siswa di sekolah.

\section{Kajian Literatur}

\section{Remaja}

Masa pertumbuhan seorang anak menjadi dewasa ditandai dengan adanya perubahan secara fisik, psikologis, mental dan emosional, sering di sebut dengan masa remaja. Menurut Suherman (2007: 103), remaja (adolescense) diartikan sebagai sesuatu yang "tumbuh" atau "tumbuh menjadi dewasa", secara luas mencakup proses kematangan mental, emosional, social, dan fisik. Menurut Parson \& Grinder (dalam Suherman, 2007: 105), berdasarkan perspektif belajar sosial, masa remaja adalah masa senang bergaul dengan teman sebaya karena dipandang menewarkan social reward dan peer status needs yang lebih menarik dari pada keluarga. Pada masa ini sering kali remaja mulai senang bergaul dan berkelompok baik di lingkungan sekolah maupun di lingkungan bermainnya.

Bandura dalam Suherman (2007: 105) menambahan remaja berusaha mempelajari respons-respons sosial dengan mengamati dan mengimitasi berbagai perilaku teman sebayanya. Remaja lebih mudah merespon teman sebayanya mengikuti dan mempelajari perubahan kebiasaan yang di lakukan dalam kelompok bermainnya yang mereka anggap sebagai tren dan kemudian mereka menirukannya.

Berdasarkan beberapa pendapat pada pembahasan terdahulu maka dapat disimpulkan bahwa remaja adalah masa peralihan dari masa anak ke masa dewasa yang mengalami perubahan atau perkembangan memasuki masa dewasa yang diantaranya mengalami perubahan kematangan mental, emosional, sosial, fisik, dan ditandai dengan adanya rasa senang bergaul dan lebih mudah menyesuaikan diri dengan teman sebaya yang mereka anggap sebagai lingkungan yang unik dan nyaman untuk mengaktualisasikan diri dan mencari identitas bagi dirinya. 
Fase usia remaja merupakan salah satu periode dalam rentang kehidupan seseorang. Menurut Yusuf (2009: 10) fase remaja meliputi remaja awal (usia 2-15 tahun), remaja madya (usia 15-18 tahun), dan remaja akhir (usia 19-22 tahun). Sekolah Menengah Pertama (SMP) merupakan jenjang pendidikan yang di tempuh oleh remaja pada umumnya. Usia rata-rata remaja yang duduk di bangku SMP adalah remaja yang berkisar antara 12-15 tahun. Pada penelitian ini yang digunakan sebagai subjek penelitian adalah siswa kelas VIII SMP Negeri 3 Bantul.

Perkembangan dalam masyarakat (dewasa) mempunyai banyak aspek yang kurang lebih berhubungan dengan masa puber. Termasuk perubahan dalam intelektual yang khas dari cara berpikir memungkinkan remaja untuk mencapai integrasi dalam hubungan sosial orang dewasa dan merupakan ciri khas dari periode perkembangan remaja.

Menurut Yusuf (2009: 22) tugas-tugas perkembangan remaja adalah sebagai berikut:

1. Menerima fisiknya sendiri berikut keragaman kualitasnya (seperti kecantikan, keberfungsian, dan keutuhan), Mencapai kemandirian emosional dari orang tua atau figur-figur yang mempunyai otoritas (mengembangkan sikap respek terhadap orang tua dan orang lain),

2. Mengembangkan keterampilan komunikasi interpersonal (lisan dan tulisan),

3. Mampu bergaul dengan teman sebaya atau orang lain secara wajar,

4. Menemukan manusia model yang dijadikan pusat identifikasi,

5. Menerima diri sendiri dan memiliki kepercayaan terhadap kemampuannya sendiri,

6. Memperoleh self-control kemampuan mengendalikan sendiri atas dasar skala nilai, prinsip-prinsip atau falsafah hidup,

7. Mampu meninggalkan reaksi dan penyesuaian diri sikap dan perilaku yang kekanak-kanakan,

8. Mengembangkan keterampilan intelektual dan konsep-konsep yang diperlukan bagi warga negara,

9. Memilih dan mempersiapkan karir (pekerjaan),

10. Memiliki sikap positif terhadap pernikahan dan hidup berkeluarga (meyakini bahwa pernikahan merupakan salah satu yang mengahalalkan hubungan seksual priawanita),

11. Mengamalkan ajaran agama yang dianut.

Upaya untuk mewujudkan tugas perkembangan remaja, tentu tidak akan maksimal tanpa adaya sesuatu yang dapat mengarahkan, peran serta guru BK atau konselor dalam memberikan layanan bimbingan dan konseling di sekolah secara komprehensif.

\section{Kepercayaan Diri}

Kepercayaan diri menjadi salah satu faktor yang dapat berpengaruh terhadap keberhasilan belajar siswa. Menurut Afiatin dan Andayani (dalam Ghufron dan Rini, 2010: 34) kepercayaan diri merupakan aspek kepribadian yang berisi keyakinan tentang kekuatan, kemampuan dan keterampilan yang dimilikinya. Seseorang yang memiliki kepercayaan diri biasanya menganggap bahwa dirinya mampu melakukan segala sesuatu yang dihadapinya dengan kemampuan yang dimilikinya. Sesuai dengan pendapat Kumara (dalam Ghufron dan Rini, 2010:34) kepercayaan diri merupakan ciri kepribadian yang mengandung arti keyakinan terhadap kemampuan diri sendiri. Adapun Willis (dalam Ghufron dan Rini, 2010:34) menyatakan bahwa kepercayaan diri adalah keyakinan bahwa seseorang mampu menanggulangi suatu masalah dengan situasi terbaik dan dapat memberikan sesuatu yang menyenangkan bagi orang lain.

Berdasarkan beberapa pendapat mengenai kepercayaan diri, peneliti menyimpulkan bahwa kepercayaan diri adalah karakteristik pribadi seseorang yang di dalamnya terdapat keyakinan akan kemampuan diri dan mampu mengembangkan serta mengolah dirinya sebagai pribadi yang mampu menanggulangi suatu masalah dengan situasi terbaik.

Pendapat Lauster (dalam Ghufron dan Rini, 2010:35) menjelaskan bahwa ciri-ciri kepercayaan diri antara lain keyakinan kemampuan diri, optimis, objektif, bertanggung jawab, rasional dan realistis. Menurut Mardatilah (2010: 176) seseorang yang memiliki kepercayaan diri tentunya memiliki ciri-ciri:

1. Mengenal dengan baik kekurangan dan kelebihan yang dimilikinya lalu mengembangkan potensi yang dimilikinya. 
2. Membuat standar atas pencapaian tujuan hidupnya lalu memberikan penghargaan jika berhasil dan bekerja lagi jika tidak tercapai.

3. Tidak menyalahkan orang lain atas kekalahan atau ketidak berhasilannya namun lebih banyak instrospeksi diri sendiri.

4. Mampu mengatasi perasaan tertekan, kecewa, dan rasa ketidak mampuan yang menghingapinya.

5. Mampu mengatasi rasa kecemasan dalam dirinya.

6. Tenang dalam menjalankan dan menghadapi segala sesuatunya.

7. Berpikir positif dan

8. Maju terus tanpa harus menoleh kebelakang.

Dari penjelasan beberapa ciri-ciri kepercayaan diri tersebut, dapat dijadikan sebagai tolak ukur penelitian dalam menilai siswa yang memiliki kepercayaan diri tinggi atau rendah. Aspek-aspek tersebut dapat dengan mudah diamati dalam kehidupan sehari-hari sehingga hasilnya akan lebih efektif jika digunakan sebagai dasar penelitian.

Menurut Mastuti (2008: 48) faktor-faktor yang mempengaruhi kepercayaan diri antara lain: orangtua, masyarakat, teman sebaya, dan konsep diri. Pendapat dari Iswidharmanjaya (2004: 72) faktor luar yang mempengaruhi kepercayaan diri yaitu lingkungan keluarga, lingkungan masyarakat, lingkungan sekolah, teman sebaya, dan media massa. Mengkaji dari faktor-faktor yang mempengaruhi kepercayaan diri, peneliti mengambil kesimpulan bahwa kepercayaan diri dipengaruhi oleh dua faktor, yaitu faktor internal dan faktor eksternal. Faktor internal yaitu konsep diri seseorang, yakni kesadaran seseorang akan keadaan yang membawa pengaruh besar dalam penentuan tingkah laku seseorang. Terbentuknya konsep diri ini berdasarkan persepsi mengenai sikap-sikap lain terhadap seseorang dan atas dasar pengalaman terhadap lingkungan keluarga. Rasa percaya diri akan timbul dan berkembang sesuai dengan kesadaran akan keyakinan dan kemampauan diri untuk menerima dan memahami orang lain sebagai hubungan interaksi yang saling mendukung, baik keluarga atau dalam pergaulan dengan lingkungan sosial.

Adapun faktor eksternalnya yaitu lingkungan keluarga dimana lingkungan keluarga akan memberikan pembentukan awal terhadap pola kepribadian seseorang. Selain itu lingkungan formal atau sekolah, dimana sekolah adalah tempat kedua untuk senantiasa mempraktikkan rasa percaya diri seseorang atau siswa yang didapat dari lingkungan keluarga kepada temantemannya dan kelompok bermain. Besar kemungkinan kepercayaan diri seseorang juga akan berpengaruh pada motivasi belajar siswa untuk mampu berprestasi baik dalam bidang akademik maupun dalam bidang non akademik.

\section{Prestasi Belajar}

Prestasi belajar menjadi salah satu parameter keberhasilan belajar siswa di sekolah. Menurut Syah (2008: 91) prestasi belajar adalah taraf keberhasilan seorang murid dalam mempelajari materi pelajaran di sekolah yang dinyatakan dalam bentuk skor yang diperoleh dari hasil tes mengenai sejumlah materi pelajaran tertentu. Menurut Syah (2010: 149) prestasi belajar merupakan hasil belajar atau hasil penilaian secara menyeluruh. Diperkuat oleh pendapatnya Sudjana (2010: 22) bahwa prestasi belajar adalah kemampuan-kemampuan yang dimiliki siswa setelah siswa menerima pengalaman belajar. Mengkaji dari beberapa pendapat mengenai pengertian prestasi belajar, peneliti mengambil kesimpulan bahwa prestasi belajar adalah hasil dari sebuah proses belajar yang baik, ditandai dengan adanya kemampuan pengausaan materi tentang pelajaran terkait dan merupakan hasil penilaian secara menyeluruh.

Menurut Syah, (2010: 115-116) Siswa yang berprestasi dalam belajar memiliki ciri-ciri perubahan yang diantaranya: perubahan intensional, perubahan positif dan aktif, dan perubahan efektif dan fungsional. Menurut Slameto (2010: 54) beberapa faktor yang mempengaruhi prestasi belajar antara lain faktor intern dan faktor ekstern.

1 Faktor intern

Faktor intern adalah faktor yang timbul dari dalam diri individu itu sendiri, adapun yang dapat digolongkan kedalam faktor intern yaitu kecerdasan atau intelegensi, minat, bakat, dan motivasi.

2 Faktor ekstern

Adapun faktor-faktor ekstern yang dapat mempengaruhi prestasi belajar yang sifatnya diluar diri siswa yaitu: keadaan keluarga, keadaan sekolah, dan lingkungan masyarakat. 


\section{Perencanaan Karir}

Perencanaan karir adalah aspek penting yang perlu dimiliki oleh siswa dalam menentukan studi lanjut yang sesuai dengan bakat dan minat siswa. Perencanaan karir menurut Person dalam Winkel dan Hastuti (2006:407) suatu cara untuk membantu siswa dalam memilih suatu bidang karir yang sesuai dengan potensi mereka, sehingga dapat cukup berhasil dalam pekerjaannya. Peneliti menyimpulkan bahwa perencanaan karir merupakan suatu proses pemilihan sasaran karir, dengan mempertimbangkan terhadap peluang, kesempatan, kendala dan pilihan-pilihan karir untuk mencapai dari tujuan karir yang dinginkan yang sesuai dengan bakat, minat dan potensi yang dimiliki siswa.

Adapun tujuan perencanaan karir menurut Simamora (2011: 505):

1. Menyadari diri sendiri terhadap peluangpeluang, kesempatan-kesempatan, kendalakendala, pilihan-pilihan dan konsekuensikonsekuensi,

2. Mengidentifikasi tujuan-tujuan yang berkaitan dengan karir

3. Menyusun program kerja, pendidikan dan yang berhubungan dengan pengalamanpengalaman yang bersifat pengembangan guna menyediakan arah, waktu dan urutan langkah-langkah yang diambil untuk meraih tujuan karir.

Berdasarkan pendapat Simamora terkait dengan tujuan perencanaan karir, dapat dijelaskan bahwa tujuan perencanaan karir adalah untuk menyadari terhadap adanya peluang, kesempatan, serta kendala dan pilihan, dan juga mengidentifikasi tujuan-tujuan yang berkaitan dengan karir, peyusunan program kerja, pendidikan dan pengalaman yang berifat pengambangan dalam rangka meraih tujuan karir.

Menuru Suherman (2007: 116) indikatorindikator dalam perencanaan karir antara lain mempelajari informasi karir, membicarakan karir dengan orang dewasa, mengikuti pendidikan tambahan (kursus), berpartisipasi dengan kegiatan ekstrakurikuler, mengetahui persyaratan pendidikan untuk karir yang diinginkan, dapat merencanakan apa yang harus di lakukan setelah tamat dari sekolah, mengetahui cara dan kesempatan memasuki karir yang dinginkan, serta mengatur waktu luang secara efektif. Menurut
Jordan (dalam Yusuf, 2009: 27) aspek-aspek dalam perencanaan karir meliputi pemahaman karir, mencari informasi, sikap, perencanaan dan pengambilan keputusan, dan keterampilan karir.

Berdasarkan pendapat Jordan terkait dengan aspek-aspek perencanaan karir, peneliti menyimpulkan bahwa tugas-tugas perkembangan karir remaja adalah siswa harus memiliki pemahaman tentang karir, mencari informasi, sikap, bertanggung jawab terhadap keputusan karir, mampu membuat perencanaan, pengambilan keputusan, dan memiliki keterampilan atau kompetensi yang berhubungan dengan karir yang dipilihnya.

Upaya dalam mewujudkan tujuan perencanaan karir tentu harus diimbangi dengan kepercayaan diri dan kemaksimalan hasil belajar atau prestasi belajar yang baik karena kepercayaan diri dan prestasi belajar merupakan bagian dalam perencanaan karir siswa. Berkaitan dengan kepercayaan diri dan prestasi belajar, hal ini juga dijelaskan pada faktor-faktor yang mempengaruhi dalam perencanaan karir. Salah satu faktor yang mempengaruhi adalah faktor internal berkaitan dengan percaya diri, bakat dan minat serta prestasi belajar. Hal ini tentu harus diperhatikan dan diketahui oleh siswa, karena faktor-faktor perencanaan karir ini dapat mempengaruhi upaya pencapaian tujuan dalam perencanaan karir seseorang.

Menurut Parson dan Williamson (dalam Suherman, 2007: 57) faktor yang mempengaruhi perencanaan karir adalah kemampuan (abilities), minat (interest) dan prestasi (achievement). Adapun penjelasan dari ketiga faktor tersebut adalah sebagai berikut.

1. Kemampuan, yaitu kepercayaan diri terkait dengan bakat yang menonjol disuatu bidang usaha kognitif, bidang keterampilan, atau bidang kesenian. Sekali terbentuk suatu kemampuan dapat menjadi bekal yang memungkinkan untuk memasuki berbagai bidang pekerjaan atau saat memasuki jenjang perguruan tinggi pada suatu bidang tertentu. Seseorang yang memiliki kemampuan atau bakat yang menonjol biasanya memiliki tingkat kepercayaan diri yang cukup tingi dalam mengaktualisasikan dirinya.

2. Minat, yaitu kecenderungan yang agak menetap kepada seseorang untuk merasa tertarik pada suatu bidang tertentu dan merasa 
senang bergaul atau bergabung dalam berbagai kegiatan yang berkaitan dengan bidang tersebut.

3. Prestasi, yaitu suatu hasil belajar (prestasi belajar), yang didapatkan dari suatu kemampuan individu yang didapatkan siswa dari usaha belajar.

Adapun manfaat dari seseorang yang memiliki perencanaan karir, menurut Sukardi dan Sumiati (1993: 24) yaitu persiapan pengambilan keputusan, mengembangkan kepercayaan diri, menemukan makna aktivitas masa sekarang, mengenal berbagai kesempatan, mengetahui persiapan yang harus dilakukan, dan mempersiapkan perencanaan hidup.

Berdasarkan beberapa teori yang menjelaskan bahwa adanya hubungan antara kepercayaan diri dengan prestasi belajar, hubungan kepercayaan diri dengan perencanaan karir, dan hubungan antara prestasi belajar dengan perencanaan karir, penelitian ini akan meneliti ada atau tidaknya hubungan antara kepercayaan diri dengan prestasi belajar dan perencanaan karir dengan menghubungkan ketiga variabel tersebut.

Menurut Parson dan Williamson dalam Suherman (2007: 57) faktor yang mempengaruhi perencanaan karir adalah kemampuan (abilities) dan prestasi (achievement). Adapun penjelasan dari dua faktor tersebut adalah sebagai berikut.

1. Kemampuan dalam hal ini terkait dengan bakat yang menonjol disuatu bidang usaha kognitif, bidang keterampilan, atau bidang kesenian. Sekali terbentuk suatu kemampuan dapat menjadi bekal yang memungkinkan untuk memasuki berbagai bidang pekerjaan atau saat memasuki jenjang perguruan tinggi pada suatu bidang tertentu. Seseorang yang memiliki kemampuan atau bakat yang menonjol diimbangi dengan sikap kepercayaan diri yang baik akan menghasilkan aktualisasi diri yang positif.

2. Prestasi, yaitu suatu hasil belajar (prestasi belajar), yang didapatkan dari suatu kemampuan individu yang didapatkan siswa dari hasil belajar. Dengan prestasi belajar yang dimiliki, secara tidak langsung individu telah merencanakan karirnya, karena untuk meraih sebuah prestasi itu dilakukan dengan sebuah proses dan perencanaan yang matang dalam belajar sehingga hasil nilainya sangat memuaskan.
Berdasarkan pendapat Parson dan Williamson, peneliti mengambil kesimpulan bahwa adanya hubungan yang signifikan antara variabel kepercayaan diri, prestasi belajar dan perencanaan karir.

\section{Metode Penelitian}

Penelitian menggunakan pendekatan kuantitatif dengan jenis korelasional. Penentuan subjek penelitian dengan menggunakan teknik random sampling. Subjek penelitian ini sebanyak 93 siswa, yang merupakan $50 \%$ dari total populasi sebanyak siswa 186 (responden) kelas VIII di SMP Negeri 3 Bantul. Instrumen yang digunakan yaitu berupa angket. Metode analisis data menggunakan analisis korelasi linear berganda.

\section{Hasil Penelitian Dan Pembahasan}

Tujuan uji linieritas adalah untuk mengetahui linieritas hubungan antara masing-masing variabel penelitian. Teknik analisis data untuk menguji hubungan linier antar variabel yang satu dengan yang lain menggunakan uji signifikan F. Linier atau tidaknya suatu hubungan dapat dilihat dari peluang galat (p) melalui harga (F). Hubungan kedua variabel dikatakan linier jika p >0,05 dan sebaliknya jika $\mathrm{p}<0,05$ maka sebaran tidak linier. Uji linieritas yang digunakan dalan penelitian ini adalah anova. Uji linieritas dalam penelitian ini bertujuan untuk mengetahui ada tidaknya korelasi antara kepercayaan diri dengan prestasi belajar dan perencanaan karir siswa kelas VIII SMP Negeri 3 Bantul. Hasil uji linieritas dapat diketahui pada Tabel 1. Pada Tabel 1 terlihat bahwa ada hubungan linier antara kepercayaan diri, prestasi belajar, dengan perencanaan karir pada siswa kelas VIII SMP Negeri 3 Bantul. 


\section{KOMARA}

Tabel 1

Uji Linieritas Hubungan Kepercayaan Diri, Prestasi Belajar dan Perencanaan Karir

\begin{tabular}{lrrl}
\hline \multicolumn{1}{r}{ Variabel } & F Hitung & P Value & Hasil \\
\hline Kepercayaan & 0,910 & 0,594 & Linier \\
Diri $\left(\mathrm{X}_{1}\right)$ dan & & & \\
Perencanaan & & & \\
Karir $(\mathrm{Y})$ & & & \\
Prestasi & 0,779 & 0,789 & Linier \\
Belajar $\left(\mathrm{X}_{2}\right)$ & & & \\
dan & & & \\
Perencanaan & & & \\
Karir $(\mathrm{Y})$ & & & \\
\hline
\end{tabular}

Berdasarkan hasil analisis pearson correlation, dapat diketahui bahwa hubungan antara kepercayaan diri dengan perencanaan karir mempunyai nilai $\mathrm{p}=0,0000$ atau lebih kecil dari 0,05 sehingga dapat disimpulkan bahwa ada hubungan yang signifikan antara kedua variabel tersebut. Nilai koefisien korelasi sebesar 0,727 atau positif, dengan demikian semakin tinggi kepercayaan diri maka perencanaan karir semakin tinggi pula dan sebaliknya apabila kepercayaan diri rendah maka perencanaan karir juga akan semakin rendah.

Hubungan antara prestasi belajar siswa dengan perencanaan karir mempunyai nilai $\mathrm{P}=$ 0,0000 atau lebih kecil dari 0,05 sehingga dapat disimpulkan bahwa ada hubungan yang signifikan antara kedua variabel tersebut. Nilai koefisien korelasi sebesar 0,194 atau positif, dengan demikian semakin tinggi prestasi siswa maka perencanaan karir semakin tinggi pula dan sebaliknya apabila prestasi siwa rendah maka perencanaan karir juga akan semakin rendah.

Hubungan antara kepercayaan diri, prestasi belajar terhadap perencanaan karir mempunyai nilai $\mathrm{p}=0,0000$ atau lebih kecil dari 0,05 sehingga dapat disimpulkan bahwa ada hubungan yang signifikan kepercayaan diri, prestasi belajar terhadap perencanaan karir. Nilai koefisien korelasi sebesar 0,727 atau positif, dengan demikian semakin tinggi kepercayaan diri dan prestasi siswa maka perencanaan karir semakin tinggi pula dan sebaliknya apabila kepercayaan diri dan prestasi siswa rendah maka perencanaan karir juga akan semakin rendah. Hasil analisis pearson correlation dapat dilihat pada Tabel 2 .
Tabel 2

Hasil Uji Korelasi Kepercayaan Diri, Prestasi Belajar dan Perencanaan Karir

\begin{tabular}{lcc}
\hline \multicolumn{1}{c}{ Hubungan } & $\mathrm{r}_{\mathrm{xy}}$ & $\mathrm{P}$ \\
\hline $\begin{array}{l}\text { 1.Kepercayaan Diri }\left(\mathrm{X}_{1}\right)- \\
\text { Perncanaan Karir }(\mathrm{Y})\end{array}$ & 0,727 & 0,000 \\
$\begin{array}{l}\text { 2.Prestasi Belajar }\left(\mathrm{X}_{2}\right)- \\
\text { Perencanaan Karir (Y) }\end{array}$ & 0,194 & 0,000 \\
3.Kepercayaan Diri $\left(\mathrm{X}_{1}\right)$ dan & 0,727 & 0,000 \\
Prestasi Belajar $\left(\mathrm{X}_{2}\right)-$ & & \\
Perncanaan Karir $(\mathrm{Y})$ & & \\
\hline Sumber : Data Primer, 2015 & &
\end{tabular}

Tingkat pengaruh dari variabel-variabel independen $\left(\mathrm{X}_{1}, \mathrm{X}_{2}\right)$ terhadap variabel dependen (Y) dapat diketahui melalui uji $\mathrm{t}$ dan uji F. Uji $\mathrm{t}$ digunakan untuk menguji koefisien regresi secara individual sedangkan uji $\mathrm{F}$ digunakan untuk menguji koefisien regresi secara bersama-sama atau serempak. Hasil uji $\mathrm{t}$ dan uji $\mathrm{F}$ sebagai berikut:

1. Pengujian terhadap variabel kepercayaan diri siswa $\left(\mathrm{X}_{2}\right)$

Berdasarkan hasil perhitungan SPSS for Windows Release 16.00 diperoleh nilai t hitung sebesar 9,676 dengan sig.t sebesar 0,035 (9,676>1,986). Dengan demikian, Ho ditolak dan Ha diterima sehingga dapat dimaknai bahwa ada hubungan positif kepercayaan diri dengan perencanaan karir pada siswa kelas VIII SMP Negeri 3 Bantul.

2. Pengujian terhadap variabel prestasi belajar $\left(\mathrm{X}_{2}\right)$

Berdasarkan hasil perhitungan SPSS for Windows Release 16.00 diperoleh nilai t hitung sebesar -0,227 dengan sig.t sebesar 0,000 (0227<-1,986). Dengan demikian, Ho ditolak dan Ha diterima sehingga dapat dimaknai bahwa ada hubungan positif prestasi belajar dengan perencanaan karir pada siswa kelas VIII SMP Negeri 3 Bantul.

3. Uji F (uji bersama-sama atau serempak)

Uji F digunakan untuk membuktikan pengaruh secara bersama-sama dari variabel independen terhadap variabel dependen. Berdasarkan hasil pengujian secara bersama-sama (Uji F), diperoleh nilai $\mathrm{F}$ hitung sebesar 50,403 dengan signifikansi 0,000 dan nilai $F$ tabel sebesar 3,098. Nilai $F$ hitung lebih besar dibandingkan $\mathrm{F}$ tabel $(50,403>3,098)$ sehingga 
Ho ditolak dan Ha diterima. Dengan demikian dapat disimpulkan bahwa ada hubungan positif kepercayaan diri dengan prestasi belajar dan perencanaan karir siswa kelas VIII SMP Negeri 3 Bantul.

Koefisien determinasi $\left(\mathrm{R}^{2}\right)$ digunakan untuk mengetahui besarnya kontribusi pengaruh dari variabel independen terhadap variabel dependen. Nilai koefisien determinasi $\left(\mathrm{R}^{2}\right)$ sebesar 0,528 menunjukan bahwa besar perencanaan karir yang disebabkan oleh kepercayaan diri dan prestasi belajar sebesar $52,8 \%$ dan sisanya sebesar $47,2 \%$ disebabkan oleh variabel lain diluar kepercayaan diri dan prestasi belajar.

Hasil penelitian ini menunjukkan bahwa ada hubungan positif antara variabel kepercayaan diri dan prestasi belajar terhadap perencanaan karir pada siswa kelas VIII SMP Negeri 3 Bantul. Semakin tinggi kepercayaan diri dan prestasi belajar maka perencanaan karir semakin tinggi dan sebaliknya apabila kepercayaan diri dan prestasi belajar rendah maka perencanaan karir akan semakin rendah. Setiap perubahan yang terjadi pada kepercayaan diri dan prestasi belajar akan berpengaruh pada terjadinya perencanaan karir pada siswa.

Kepercayaan diri pada siswa dapat mengembangkan bakat, minat, dan potensi yang ada di dalam diri siswa sehingga bisa berkembang menjadi sebuah kesuksesan. Siswa yang memiliki kepercayaan diri cenderung mampu merencanakan karirnya dari pada siswa yang kepercayaan dirinya rendah.

\section{Simpulan}

Berdasarkan hasil penelitian dapat disimpulkan bahwa ada hubungan positif antara kepercayaan diri dan prestasi belajar dengan perencanaan karir pada siswa kelas VIII SMP Negeri 3 Bantul. Hasil penelitian ini bermanfaat bagi konselor sebagai gambaran tentang kondisi kepercayaan diri, prestasi belajar, dan perencanaan karir siswa yang dapat dijadikan bahan pertimbangan dalam menyusun program layanan bimbingan dan konseling bagi siswa di sekolah.

\section{Referensi}

Afifi, John. (2014). 1 Menit Mengatasi Rasa Percaya Diri Anda. Yogyakarta: Flash Books.

Arikunto, Suharsimi. (2010). Prosedur Penelitian Suatu Pendekatan Praktik. Jakarta: Rineka Cipta.

Azwar, Saefuddin. (2011). Psikologi Intelegensi. Yogyakarta: Pustaka Pelajar.

Desmita. (2005). Psikologi Perkembangan. PT. Bandung: Remaja Rosdakarya.

Gibson, Robert dan Mitchell, Marianne. (2011). Bimbingan dan Konseling. Yogyakarta: Pustaka Pelajar.

Gladding, Samuel T. (2012). Konseling Profesi Yang Menyeluruh. Jakarta: Indeks.

Hamid, Hamdan. (2013). Pengembangan Sistem Pendidikan di Indonesia. Bandung: Pustaka Setia.

Harlock, Elizabeth. (2002). Psikologi Perkembangan Suatu Pendekatan Sepanjang Rentan Kehidupan. Jakarta: Erlangga.

Hasan, M. Iqbal. (2008). Pokok-Pokok Materi Statistik 1 (Statistik Deskriptif). PT. Jakarta: Bumi Aksara.

Iswidharmanjaya, Derry Dkk. (2004). Satu Hari Menjadi Lebih Percaya Diri. Jakarta: PT. Elex Media Komputindo Kelompok Gramedia.

Kummerow, JM. (2001). New Direction in Career Planning and the workplace.

Mastuti, Indri. (2008). 50 Kiat Percaya Diri. HiJakarta: Frest Publishing.

Mardatillah. (2010). Pengembangan Diri. STIE Balikpapan: Madani.

Nuriksan. Ahmad Juntika. (2010). Bimbingan dan Konseling Dalam Berbagai Latar Kehidupan. Jakarta: PT. Refika Aditama.

Prayitno dan Erman Amti. (2008). Dasar-Dasar Bimbingan Dan Konseling. Jakarta: Rineka Cipta.

Risnawati, Rini dan M. Nur Ghufron. (2010). Teori-Teori Psikologi. Yogyakarta: Ar-Ruzz Media Group.

Santrock, John W. (2007). Remaja. Jakarta: Erlangga.

Sarastika, Pradipta. (2014). Buku Pintar Tampil Percaya Diri. Yogyakarta: Araska.

Simamora, Henry. (2011). Manajemen Sumber Daya Manusia. Yogyakarta: YK.

Slameto. (2010). Belajar \& Faktor-Faktor Yang Mempengaruhinya. Jakarta: Rineka Cipta. 


\section{KOMARA}

Sugiyono. (2010). Metode Penelitian Pendidikan Pendekatan Kuantitatif, Kualitatif dan $R \& D$. Bandung: Alfabeta.

Suhesti, Endang Ertiati. (2012). Bagaimana Konselor Sekolah Bersikap?. Yogyakarta: Pustaka Pelajar.

Suherman, Uman. (2010). Konseling Karir Sepanjang Rentan Kehidupan. Bandung: UPI.

Sukardi, Dewa Ketut dan Sumiati, Desar Made. (1993). Panduan Perencanaan Karir. Surabaya: Usaha Nasional.

Sukaria. (2006). Kemampuan Menyelesaikan Masalah Ditinjau dari Kepercayaan Diri dan Dukungan Sosial pada Remaja Akhir. Thesis. Fakultas Psikologi UGM. Yogyakarta.

Susilo, M. Joko. (2014). Pedoman Penulisan Skripsi. Fakultas Keguruan dan Ilmu Pendidikan Universitas Ahmad Dahlan Yogyakarta 2014. Yogyakarta.
Supriatna, Mamat. (2011). Bimbingan Dan Konseling Berbasis Kompetensi. Depok: Raja Grafindo Persada.

Syah, Muhibin. (2010). Psikologi Pendidikan Dengan Pendekatan Baru. Bandung: PT Remaja Rosdakarya.

$$
\text { (2013). Psikologi Belajar. }
$$

Jakarta: Rajawali Press.

Yusuf, Syamsu dan Juntika. (2010). Landasan Bimbingan dan Konseling. Bandung: PT Remaja Rosdakarya.

Yusuf, Syamsu. (2009). Program Bimbingan Dan Konseling. Bandung: Rizqi Press.

Winnkel dan Sri Hastuti. (2010). Bimbingan dan Konseling di Insitusi Pendidikan. Yogyakarta: Media Abadi. 